\title{
Opinions of High School Students and a Teacher in Teaching and Learning during Confinement by COVID-19
}

\section{Opiniones de alumnos de secundaria y de un docente en la enseñanza y el aprendizaje durante el confinamiento por el COVID-19}

\author{
Antonieta Kuz \\ Universidad Metropolitana para la educación y el trabajo (Argentina) \\ antok79@gmail.com
}

Recibido: 20/01/2021

Aceptado: $10 / 05 / 2021$

Publicado: 01/06/2021

\begin{abstract}
Globalization, new technologies, migration, international competition, market developments, transnational, environmental and political challenges are all factors that govern the acquisition of the skills and knowledge that students need to survive and get out graceful during the pandemic occasioned by the disease caused by the SARS-COV2 virus. The pandemic has accelerated many underlying issues surrounding high schools in Argentina and the challenge of preparing students for work, citizenship, and life in the 21st century. Through this study we seek to learn about how Technology of the Information and Communication (ICTs) are used by Secondary Education students of a public school in the province of Buenos Aires, specifically the prevailing digital resources that are common in the teaching-learning process. For this purpose, we combine quantitative and qualitative methodology. On the one hand, a descriptive investigation has been performed from and towards the quantitative methodology, in which the data collection has been accomplished through a questionnaire prepared for this study, which was answered by a total of 80 students. The results obtained reveal that the cell phone and, in terms of the applications that they allow, WhatsApp has been the tool they use the most. On the other hand, through a qualitative analysis, we conducted an interview with a teacher to find out her perspective. To do this, we denote, in general terms, that ,as a result of both analysis, the system was not prepared, despite the government plans implemented, making visible the complex argentine educational reality.
\end{abstract}

\section{KEYWORDS}

COVID-19; lockdown; WhatsApp; secondary students; teachers

\section{RESUMEN}

La globalización, las nuevas tecnologías, la migración, la competencia internacional, los desarrollos del mercado, los desafíos transnacionales, ambientales y políticos son factores que rigen la adquisición de las habilidades y el conocimiento que los estudiantes necesitan, para sobrevivir y salir airosos durante la pandemia ocasionada por la enfermedad causada por el virus SARS-COV2. La pandemia ha acelerado muchos problemas subyacentes en torno a las escuelas secundarias en Argentina y el desafío de preparar a los estudiantes para el trabajo, la ciudadanía y la vida en el siglo XXI. A través de este estudio buscamos conocer cómo las Tecnologías de la Información y la Comunicación (TICs) son utilizadas por estudiantes de Educación Secundaria de un colegio público de la provincia de Buenos Aires, más específicamente los recursos digitales imperantes que son comunes en el proceso de enseñanzaaprendizaje. Para ello, combinamos metodología cuantitativa y cualitativa. Por un lado, se ha realizado una investigación descriptiva desde y hacia la metodología cuantitativa, en la cual la recolección de datos se ha realizado a través de un cuestionario elaborado para este estudio, el cual fue respondido por un total de 80 estudiantes. Los resultados obtenidos revelan que el teléfono celular y en cuanto a las aplicaciones que estos permiten, el WhatsApp ha sido la herramienta que más utilizan. Por otro lado, mediante un análisis cualitativo realizamos una entrevista con una profesora para conocer su perspectiva. 
Para ello, denotamos, en términos generales, como resultado de ambos análisis, que el sistema no se preparó, a pesar de los planes gubernamentales implementados, visibilizando la compleja realidad educativa argentina.

\section{PALABRAS CLAVE}

COVID-19; Confinamiento; WhatsApp; Estudiantes secundarios, docentes

\section{CITA RECOMENDADA}

Kuz, A. (2021). Opinions of high school students and a teacher in teaching and learning during confinement by COVID-19. Revista Interuniversitaria de Investigación en Tecnología Educativa, 10, 76-90. https://doi.org/10.6018/riite.464471

\section{Main contributions of the article and future investigation lines:}

- Integrative qualitative and quantitative analysis of the technological means to maintain the pedagogical link during quarantine, considering the opinions of secondary students and the perspectives of a teacher during isolation in 2020 in Buenos Aires Argentina

- Future lines of research: Analyze other tools such as Instagram to promote student learning in the context of a pandemic and also try to analyze the correlation between those who have more access to technology and the possibilities in the teaching-learning process

\section{INTRODUCTION}

The COVID-19 pandemic is derived from the disease caused by the SARS-CoV-2 virus recognized by the World Health Organization (WHO) on 11 th March, 2020. The recently discovered Coronavirus is generally transmitted from person to person and it causes an infectious disease, which can lead to people's death. This virus has become known throughout the world for its easy transferability, causing the closure of borders. Quarantines were arranged in Argentina in 2020 to combat the Coronavirus pandemic that initially covered the entire territory, maintaining a mandatory closure. Throughout the entire year 2020, Argentina began the sequence of quarantines and restrictions.

Argentina is a country traversed by a very complex reality, due to the processes of advances and setbacks in different areas such as economic, political and also educational, gradually becoming in changing scenarios of significant heterogeneity. In March 16TH, the educational authorities of the Ministry of Education suspended face-to-face classes to prevent the spread of COVID-19. Since that date, educational establishments and classrooms have been closed and around 10 million students and 900,000 teachers at the initial, primary and secondary level have been affected. Education in Argentina, as well as many countries in the Latin American region, faces a tension that arises from trying to solve the problems of the XXI century without having yet solved those of the XX century. On the one hand, primary schooling, promoting its universalization along with countries in Latin America, such as Costa Rica, Chile and Uruguay. On the other hand, secondary education, despite being compulsory, presents difficulties in sustaining educational trajectories as well as in guaranteeing graduation. Although it is, along with Chile, Cuba and Uruguay, one of the countries in the region that shows the highest coverage rates at the secondary level, young people tend to take longer than expected to finish and repetition, over-age and desertion prevail. The Argentine educational system, due to its massiveness, compulsory nature and expansion throughout the territory, concentrated multiple demands and faced mobility restrictions but, at the same time, tried to preserve the link with students.

The country went through an uneven educational continuity according to the possibilities of connection of the students and the accompaniment of the families. With an educational system that was not prepared to teach and learn remotely nor to work habitually with technological devices. In the first stage of the quarantine, the first impulse consisted of continuing with teaching in the same way but through other means but, then, the teachers encountered 
obstacles that did not come from the virtual resource but from the restrictive reality of the country. The education system had to respond to the prolonged quarantine by implementing proposals, and the directors and professors had no time to plan or think about the role of the school at this time of a global pandemic. A surprising reality launched the educational system into action, as many students had to use the devices and means of communication to keep the pedagogical link in quarantine. In this research we will analyze the case of a secondary school in the suburbs of Buenos Aires and the situation of families, students and a teacher during isolation.

In sum, the purpose of this work is to demonstrate the results of the use of ICT resources made by the students of Buenos Aires and to find out what is their own perception. The results obtained reveal that cell phone and WhatsApp have been the tools they have used the most. We also incorporate interviews as part of the qualitative research, articulated in a proposal that tries to integrate the teaching perspective from the experience during the pandemic. Analyzing both parts of the investigation, it has been denoted that the system was not prepared, despite plans such as Conectar Igualdad which consisted in providing netbooks by the government in public educational establishments of all levels of compulsory education.

\section{ARGENTINE EDUCATIONAL CONTEXT}

If we go back to the past of Argentina, in the period between the end of the 19th century and the beginning of the 20th, society was heterogeneous due to the fact that most of the inhabitants were illiterate (Suasnabar, 2007), and the teachers who taught classes received a training with only 7 pedagogical subjects after 4 years of study. In the case of women, the possibility of attending university was prohibited and they only had access to jobs related to teaching and instruction of children at home.

In agreement with Grimson \& Tenti Fanfani (2014), it is important to demystify the phrase "good education was the old one", since the solutions of the past do not fit our reality. Today, education enjoys being a human right, the incorporation and access of women to formal education is guaranteed as a conclusive and unavoidable element for the achievement of full equality of opportunities. Due to conjunctural problems, education always remains in the background. Education is not a priority concern, at least not as much as inflation, unemployment or insecurity (Sanguinetti, 2007), deepening educational inequalities (AndereteSchwal, 2020).

Despite of the fact that $5.3 \%$ of the national GDP is allocated and that $8 \%$ of workers are dedicated to education, in Argentina, education tends to emerge in the form of backwardness (Tiramonti, 2017). According to Tedesco (2015), Argentine education today has difficulties to install a concrete work agenda that integrates inclusion strategies with a good level. In addition, around 8.3 million Argentine children during the year 2020 lived under the poverty line at the end of this year, $62.9 \%$ of the total, as a consequence of the worsening of the economic and social crisis due to the Coronavirus (Fondo de las Naciones Unidas para la Infancia, 2020).

\subsection{Context of technology in secondary education in the province of Buenos Aires}

One of the technological plans implemented by the different governments prior to the pandemic (Expósito \& Marsollier, 2020) was the "Programa Conectar Igualdad"1 (Alderete \& Formichella, 2016), which consisted in the distribution by the State of more than six million netbooks to students and teachers, of public high schools, dealing with the injustice of the digital division. This program was created during the presidency of Cristina Fernández as a State policy in which the Presidency of the Nation intervened (Giuliano \& Pacheco, 2015).

Nowadays, it has been ten years since the implementation of the Programa Conectar Igualdad (Lago-Martínez, 2015) reaching half of the schools in the country, considering that

\footnotetext{
${ }^{1}$ Programa Conectar Igualdad. website: https://cutt.ly/XkEyPo8, last visit, January 2021
} 
Internet access coverage was scarce. Until now, digital development has been dizzying, but we continue to see that today Internet coverage, in both schools and homes, is scarce.

In an economically unstable country, the program went through different stages and also breaks, which implied the suspension of the distribution of laptops to all training institutions involved. Although during the presidency of Mauricio Macri the "Conectar Igualdad" plan for both students and teachers was disolved (Marchetti \& Aguirre, 2020), the current president of the Nation, Alberto Fernández, took it up again, attentive to the context of pandemic and "quarantine". This implied the diffusion in the province of Buenos Aires of the instruction to unlock netbooks, because the equipment has a blocking system that prevents its operation when it is not regularly connected to the internet or they have been reported for loss or theft.

\subsection{The educational reality during the pandemic}

Studying during the Pandemic in Argentina, without face-to-face classes has been a challenge, since the school as such did not stop working because the virtual modality was used, with the successes and shortcomings of a work modality that had never been used before (Johnson et al., 2020). Regarding the qualifications of the students, it focuses on guiding the teaching-learning processes, taking into account that they develop in very heterogeneous and unequal conditions. However, the drawback that arose is that it could not be guaranteed that everyone has the necessary digital resources, since $44 \%$ of the students who attend state schools do not have electronic devices to do their homework and the possibility of having adequate spaces for learning at home (Ministerio de Eduación de la Nación, 2020).

The concept of ICTs (Alderete \& Formichella, 2017) emerges as the convergence of electronics, software and Telecommunications infrastructures. The association of these three concepts gives rise to a conception of the information process, in which communications opens new horizons and paradigms. ICTs go through the life of institutions, organizations and individuals (Sunkel, 2006). Due to the pandemic, the socio-educational reality and the learning environment has varied dramatically (Sunkel, 2009), readjusting communication; bringing with it the emergence of new teaching systems that are characterized by modularity and interconnection, such as WhatsApp. Analyzing the report of the Observatorio Argentinos por la Educación (2020), the most widely used technological device is the cell phone together with WhatsApp since, for most students, the cell phone is their only means of educational connection in the asynchronous mode in a precarious situation while notebooks or tablets appear to a lesser extent (Figure 1). This is because most of the students have the cell phone as the only means of educational connection.

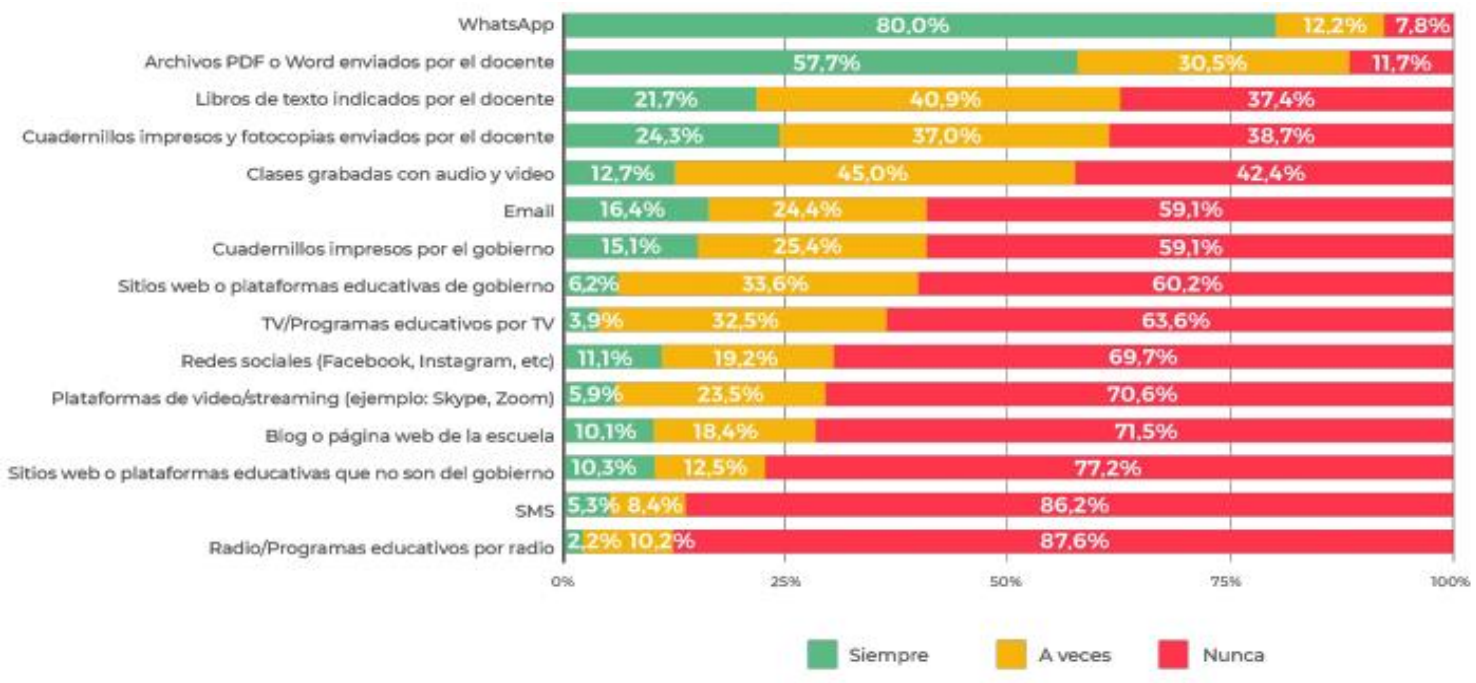

Figure 1. Means used in the proposals sent by the school. As a percentage of the total according to frequency. Year 2020.

Source: Observatorio Argentinos por la Educación (2020) 


\section{CASE STUDY}

A survey was carried out at the school to interpret and assess the vision of technology and underlying education in policies and practices related to ICT in schools, their degree of integration and synergy with other political initiatives (Grasso et al., 2017) and their ability to promote transformation and innovation.

\subsection{Methods}

Understanding what were the technology resources used by the students of the secondary school in the province of Buenos Aires and the perception of teachers. We seek to apply two methods, the qualitative and the quantitative, to obtain the knowledge that revolves around the objectives of the research. For quantitative research, we use a survey where the questions are defined as objective questions that are used to obtain detailed information from the respondents, taking into account the goal and the context. Towards the qualitative research, a teacher from a school of the suburbs was selected. The teacher selected represents an image of the Argentine's teachers today, taking into account the information about the general characteristics of the teaching staff, where the teaching profession is predominantly female and an average teacher is 36-45 age range, and lives in the suburbs (Cardini \& Sanchez, 2020). It is specified in the following specific objectives:

- Identify the particular technological resources used by students and learn the perception that students have about the pandemic and its relationship with the school.

- Comprehend the perception that the teacher has about the pandemic and its relationship with the students, school and technology recourses.

\subsection{Research focus}

This research focuses on describing and providing information about facts, starting from the nature and treatment of the data, following the non-experimental quantitative methodology in which numerical measurements are made and the results are statistically analyzed. In order to collect data, based on the objectives of the present investigation, a questionnaire was designed.

Furthermore, we have incorporated a narrative testimony as a qualitative methodological instrument (Serrano, 2009). The purpose of this work is to investigate the discussions around the testimony and its privileged place by capturing the voice of a teacher who is witness and narrator of events (Vasilachis, 2006). We work with in-depth interviews as a qualitative methodology technique, asking a teacher about her experience during classes (FernándezCarballo, 2001). Through the interview to the teacher, we seek to have a diachronic and chronological perspective through the life trajectory of the teacher and the experiences of people throughout the period of the pandemic. For this purpose, we work with a semi-structured interview, where we prepared a thematic script and the questions that are asked are open. The teacher can express her opinions, qualify her answers, and even deviate from the initial script thought by the researcher when emerging issues that need to be explored are glimpsed.

\subsection{Population studied}

To carry out the case in a practical way, we must sample the participants identifying the actors that can be selected. In our case, the scenario (Table 1) presents a group of 80 students out of a total of approximately 150 students in the school anonymously between 12 twelve and 18 years old, from grades $1 \mathrm{~A}, 1 \mathrm{~B}, 2 \mathrm{~A}, 2 \mathrm{~B}, 3 \mathrm{C}$ and $5 \mathrm{~A}$ in high school Number 53 , located in the city of La Plata, Buenos Aires. 
Table 1. Characteristics of the study population

\begin{tabular}{|c|c|c|c|}
\hline Group & Socioeconomic & $\begin{array}{c}\text { Average } \\
\text { academic } \\
\text { performance }\end{array}$ & $\begin{array}{l}\text { Average } \\
\text { age }\end{array}$ \\
\hline $\begin{array}{c}1 \mathrm{~A}, 1 \mathrm{~B}, \\
2 \mathrm{~A}, 2 \mathrm{~B}, \\
3 \mathrm{C} \text { and } 5 \\
\mathrm{~A} \text { grade }\end{array}$ & $\begin{array}{c}\text { Medium to low } \\
\text { Students have few resources in their homes } \\
\text { One of the parents has some type of informal job or } \\
\text { is assisted by the state } \\
\text { Students have lunch in the school canteen, or } \\
\text { receive food assistance with food bags }\end{array}$ & Mean & $\begin{array}{c}\text { 12-18 years } \\
\text { old }\end{array}$ \\
\hline
\end{tabular}

\section{RESULTS}

\subsection{Analysis of the questions to the students through a quantitative methodology}

The questionnaire was made addressing two different areas: affective and study. The instrument that was used to collect the data was a questionnaire that was disseminated through WhatsApp, for which it was designed. Below in Table 2 we detail the questions asked and the answers with the number of students above the total for each one, also the questions were elaborated from the objectives of this study, and the questionnaire was answered in the year 2020.

Table 2. Questions asked and the answers with the number of students above the total for each one

\begin{tabular}{|c|c|c|}
\hline Question & Reponse & $\begin{array}{l}\text { Student } \\
\text { Amount }\end{array}$ \\
\hline \multirow{6}{*}{$\begin{array}{l}\text { Did you find any problem } \\
\text { with accessing to and } \\
\text { working in virtual classes? } \\
\text { What was that drawback? } \\
\text { For example, lack of } \\
\text { contact, wrong contact, } \\
\text { lack of information, little } \\
\text { consultation time, not } \\
\text { having the material, etc. }\end{array}$} & Lack of information (the material) & 20 \\
\hline & $\begin{array}{l}\text { Not having much internet } \\
\text { (It represents the nucleus of students who have no } \\
\text { connection, or the connection is bad or they have } \\
\text { little data and they could not connect as much as } \\
\text { they wanted, or they could not use the cell phone } \\
\text { as much as they wanted since they share it with } \\
\text { their parents) }\end{array}$ & 38 \\
\hline & No inconvenience & 16 \\
\hline & I just didn't understand some questions & 6 \\
\hline & $\begin{array}{l}\text { Yes, I think that in some subjects they go } \\
\text { overboard by giving us homework and they don't } \\
\text { explain anything to us, and they don't send an } \\
\text { explanation either }\end{array}$ & 25 \\
\hline & Short consultation time & 14 \\
\hline \multirow{6}{*}{$\begin{array}{l}\text { What do you expect your } \\
\text { teacher to take into } \\
\text { account to evaluate you in } \\
\text { this new form of teaching- } \\
\text { learning virtually? }\end{array}$} & $\begin{array}{l}\text { Don't send difficult assignments. Because it is a bit } \\
\text { complicated for me. }\end{array}$ & 30 \\
\hline & Patience, since I'm not in high school to listen to it. & 14 \\
\hline & $\begin{array}{l}\text { Each work received, } \\
\text { which we cannot all deliver due to lack of } \\
\text { understanding or lack of material, etc }\end{array}$ & 20 \\
\hline & Time and form of homework & 5 \\
\hline & $\begin{array}{l}\text { Not all of us have internet and that is why } \\
\text { sometimes the delivery of homework is delayed }\end{array}$ & 13 \\
\hline & $\begin{array}{l}\text { How we strive to do homework without being in } \\
\text { school with responsibility }\end{array}$ & 5 \\
\hline
\end{tabular}




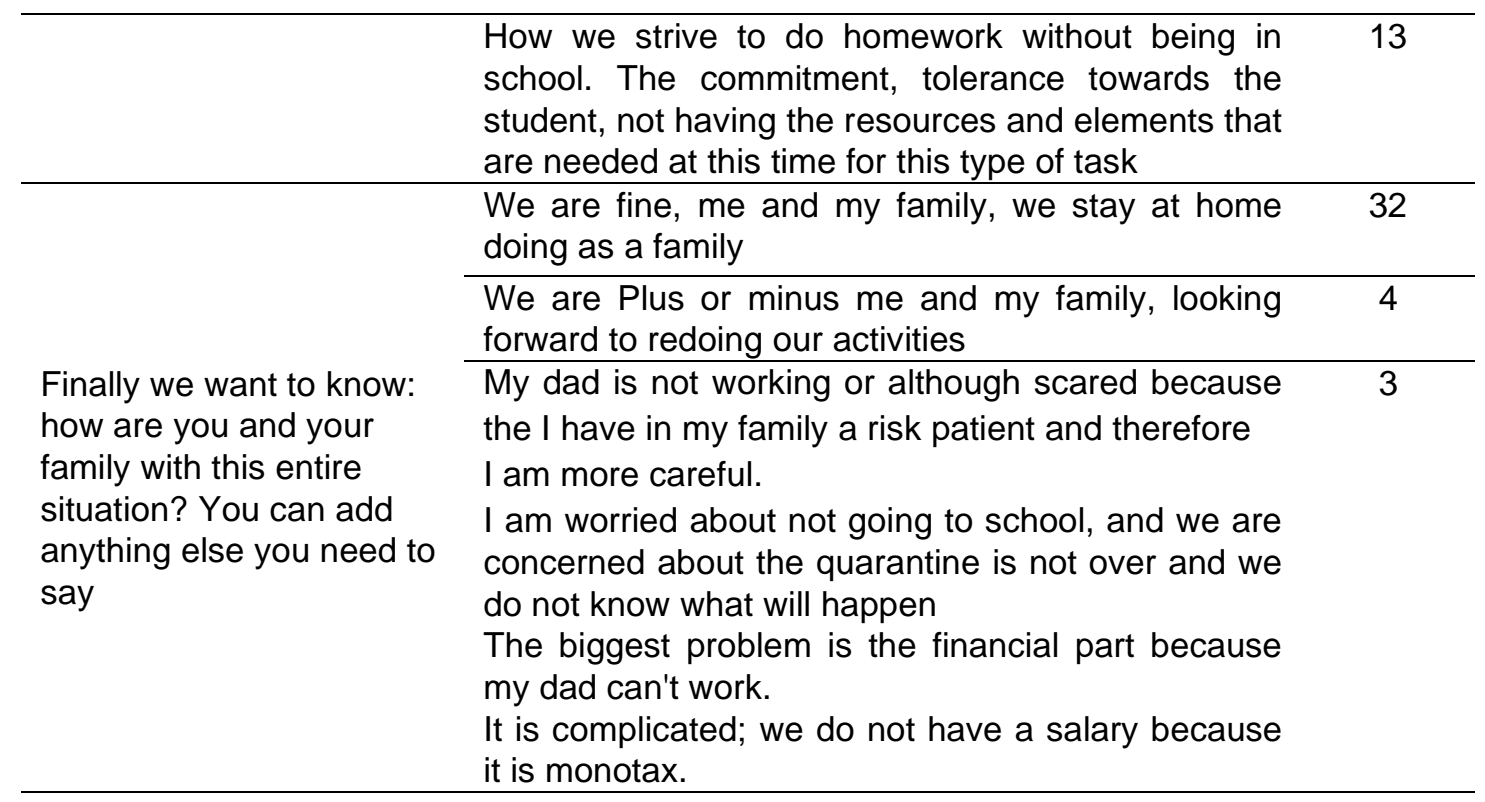

From the descriptive analysis of the data we can see in Figure 2, when faced with the question, with what device they connect to take virtual classes, that $94.2 \%$ of students carry out their activities with their cell phone, $4.3 \%$ use computers and only $1.7 \%$ use a Tablet. In addition, $76.8 \%$ of the students do not use email and $23.2 \%$ do not have. From these values and percentages one might think that the students are not interested in using the email and that lack of interest is given by the fact that they do not need it. They have no motivation to do so, therefore they do not care if they have mail or not, they do not care to check it and they usually lose the passwords. And this situation is exacerbated by the scarce possibility of accessing a digital device, as we see; only $3.4 \%$ have computers. It can also be stated that the use of the cell phone is with an asynchronous pedagogic mode, due to the scarce availability of the cell phone (in most houses there is only one phone and it is used by one of their parents).

Therefore, the data that we have presented allows us to get an idea of the state of affairs as if it was a photograph, in the middle of the measurements of prevention and physical isolation applied in Argentina, influenced directly and untimely by the ways in which students faced the 2020 teaching-learning process and socioeconomic and family problems. The scarcity of digital connectivity and computers hinders pedagogical continuity and most of the consumptions are via cell phone and using telephone data, which makes them more expensive at a critical time for the informal economy. The situation of connectivity and that many families have a single cell phone that they share among all members, is a daily problem for students, generating a digital divide and violating the right to education, since there is great difficulty in accessing to all the educational content.

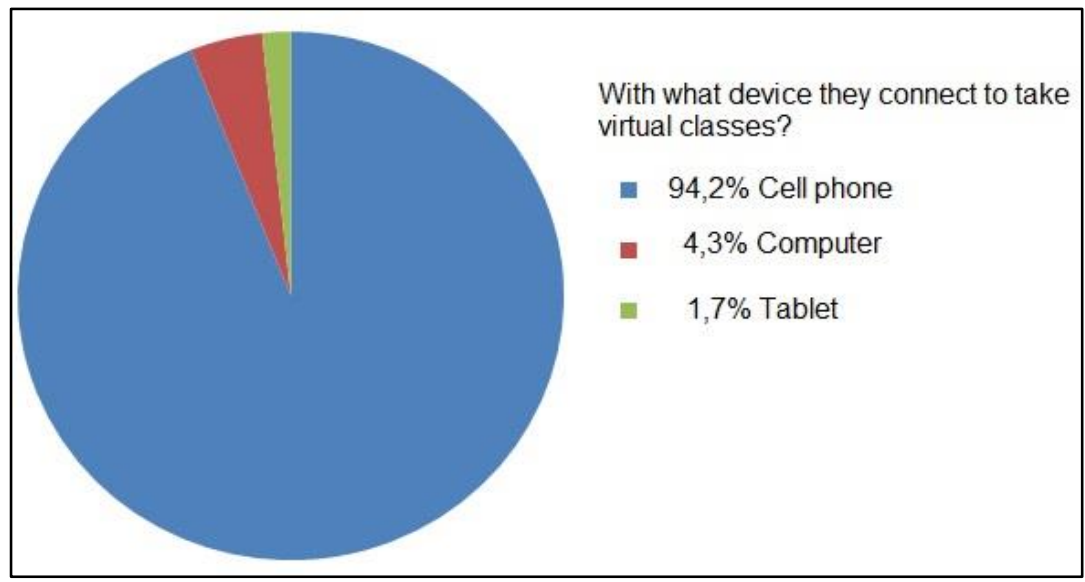

Figure 2. Percentages that reflect high cell phone use. 


\subsection{Analysis of the teacher perception through a quality methodology interview and questionnaire to a teacher}

In this section we carry out a qualitative approach (Vasilachis, 2006), investigating subjective perspectives, behaviors, experiences, interactions, actions, senses, interpreting them in a situated way, that is, placing them in the particular context in which they take place. To this end, an in-depth interview was carried out, with questions that detail the experience of the subject facing the situation of teaching classes in the context of the pandemic. The pandemic has changed the routine of teachers (Artopoulos, 2020), because education has been one of the most affected areas, which has been forced to reinvent itself to continue teaching at all levels, but especially at the secondary level. The participating subject was a teacher of around 38 years who has been teaching language for more than 10 years in the field of state management in the province of Buenos Aires. The unstructured interview was conducted in sessions during the March-September 2020 period, so that the teacher could ratify or modify the answers in the context of a sequence of quarantines and restrictions. In the sessions, she was welcomed and we explained that her participation would be reflected in an investigation, as well as the purpose of the interview and that both her first and last name would remain anonymous. Below in Table 2 we detail the results of the interview of the sessions.

Table 3. Main opinions of the teacher's interview sessions

\begin{tabular}{l}
$\quad$ Question \\
When the quarantine \\
started, did you feel \\
worried? \\
\hline Did you feel that the \\
managers accompanied \\
you in this situation of \\
uncertainty, or did you feel \\
alone? \\
\hline Do you have a computer \\
that you can use \\
exclusively, without having \\
to share it with others in the \\
home?
\end{tabular}

The first days we had the feeling that we were adrift, and then we were driven more or less by what we read on the Internet. I was three days in a row without slewing an eye. I had to put together the virtual tasks that I had to start sending because they were demanding them. During this process we feel uncertainty

The accompaniment and adaptation of the usual tasks was complex, due to the demands of the emergency, as new demands arose. I found that the driving and teaching teams were overwhelmed. Yes, in my case, but not all teachers have a personal one, many share them with their children of school age. The Internet service was regular, many times it slowed down, and did not respond to complains, in addition to power outages that affected the service.

At the beginning we tried to establish a weekly or biweekly contact with the alumni, we includes all aspects such as keeping in mind who is supporting the effort, communicating, delivering the requested tasks and who is not, or who are

What was the weekly contact with your students? experiencing family situations that are affecting them physically or emotionally. In other cases, where there are not many possibilities to contact families. Many times I had to prepare homework and give photocopies to the family who received the box with the food for the students. The family brings it solved fifteen days later when they return for a new box and state handouts as an alternative.

Did you place any emphasis on those students with more vulnerable situations?
Special emphasis has been placed on monitoring the most vulnerable populations, such as students with disabilities, single-parent families, and adolescent mothers, among others. 
Have you encountered socioeconomic difficulties in the homes of your students to follow the educational proposal?

The students are heterogeneous and in many cases do not have connectivity or a computer. But everyone has a cell phone and WhatsApp, in some cases one per family, of the father or mother, in some houses there are very complicated situations, one or both parents were left without income.

In the beginning we used a collaborative platform classroom, but we noticed that the students did not connect; perhaps one of them appeared online lockdown, what kind of software did you use to work with your students?

What attitude did they take when analyzing that students did not enter the classroom?

Why did they consider WhatsApp as a viable tool to achieve the teachinglearning process?

We tried to think of another solution since we were not being able to reach the students.

It is not the most appropriate, and the usual planning was completely upset along with the teaching-learning dynamics but considering the overflow situation it was the best we could use in the face of the pandemic.

With the face-to-face classes suspended, I have had to change my methodology to teach at a distance, which implies answering questions outside of school hours, in addition to helping those who have children. Contrary to prejudice, without classes, teaching work multiplied. There is an excess of work since it is necessary to constantly redesign and adapt the entire system, as well as, due to the lack of limit in working hours. This causes increasing stress that adds to the requirement to maintain a reasonable educational level.

With WhatsApp what is taking place in secondary school with the pandemic is the formalization of informal strategies that teachers already had, such as WhatsApp groups. The cell phone achieves a connection and also makes possible a greater possibility of pedagogical continuation. There are other resources such as the distribution of printed materials, but those who have connectivity with devices, and can interact with their teacher, and those with a booklet do not have the same school experience.

How did they use the WhatsApp and how to achieve the pedagogical continuity?

We work with other teachers with projects for smaller groups. Each teacher was assigned four or five students to work in a more individual way. Many practical works with the cell phone, for the students, but it was not easy. Many times, parents share mobile data from their phone so that the student can connect with their classmates and ask questions through social problems.

Yes, they have had motivation problems, added to

Do you consider that the students were motivated to continue? organizational difficulties with studying, social isolation since it is not the same to study and learn alone than accompanied. That is why we work with groups with activities that require exchange between peers: group work, writing letters to their friends, song lyrics written in a collaborative way, etc. 
Do you think the plan to "conectar igualdad" was effective, to be an appropriate technology for the pandemic?
Practically it had no interference; students who attend state schools do not have electronic devices to do homework. Although according to the ministry, the netbook softwares have already been updated so that they can use the "Seguimos Educando" digital platform, one of the tools created by the national state to sustain pedagogical continuity during the pandemic.

From the interpretation of the teacher's responses, we were allowed to collect the information and contrast the inequality that appears in teaching learning processes. As we can see, the teacher has contributed to respond to the challenges that the confinement measure implies from her perspectives and personal experiences. In addition, the key is the answers; it allows us to infer that teachers are making a great effort because they have the responsibility and commitment to continue supporting education. In this framework, an opportunity that opens up for students is to begin to see what works and what does not, in relation to technology and what things they can continue to sustain when they return to the classroom and face-to-face.

In Figure 3 we show the screenshots of the teacher's cell phone, some examples of tasks sent by the teacher to the students. In this case the teacher expressed the difficulty to correct through the screenshots, which led to more general corrections. The instructions show the work per project in small groups with other teachers (Sandoval, 2020). Then the students sent the tasks to the teacher's cell phone through photos with the tasks done on paper, see Figure 4, so the teacher corrected with certain difficulties.

Likewise, it can be noted that from this juncture the Internet is a space that allows teachers to continue with the teaching and learning process, valuing the role of the educator and the link between the teacher and the school from another place with the families. Since a comprehensive perspective, teachers in a context of uncertainty can understand that WhatsApp is essential to stay in contact with students and reach those who are in the most vulnerable situations, to provide pedagogical continuity and avoid abandonment. Besides, it can be observed that when the teacher talks about the selection of digital resources, she understands that she does not need to be an expert in management, because the students quickly take ownership of the technology. According to the teacher, it is ignored that despite the fact that WhatsApp is available, it allows communication and sharing documents as seen in the previous figures of photos of tasks sent by the students to the teacher, and that it is useful in the face of scarcity; from the pedagogical point of view it is a very rudimentary tool, generating frustration and fatigue.

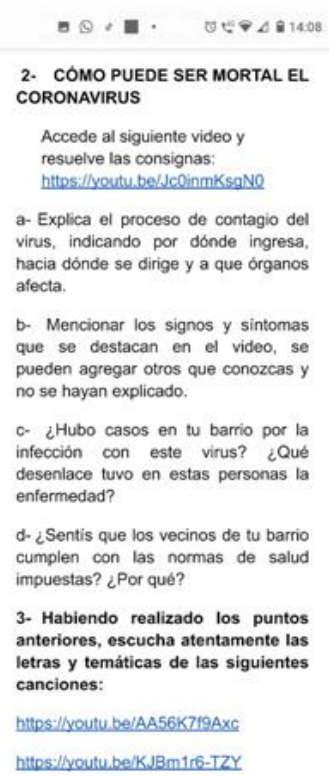

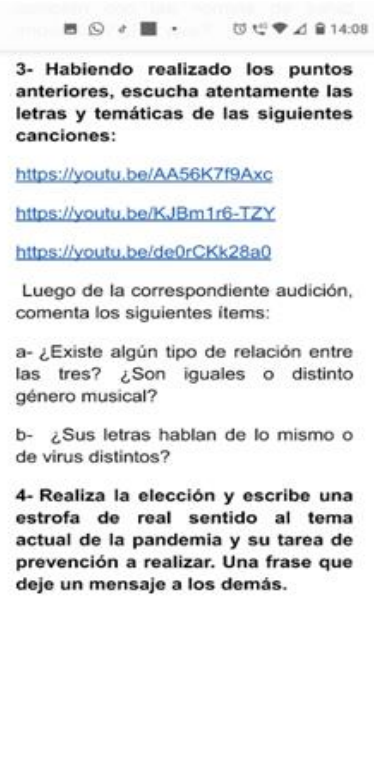

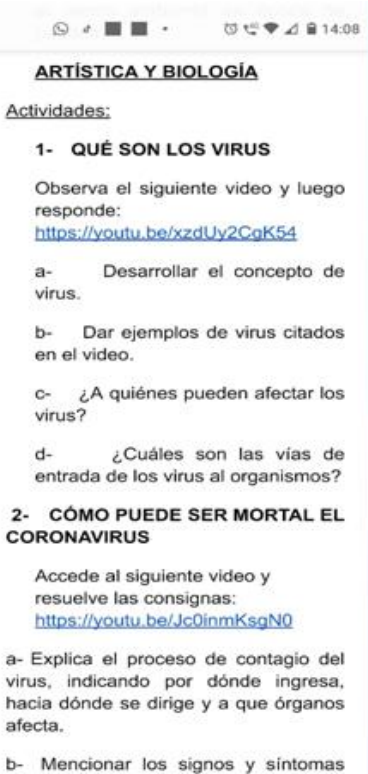

Figure 3. Screenshots of the teacher's cell phone 


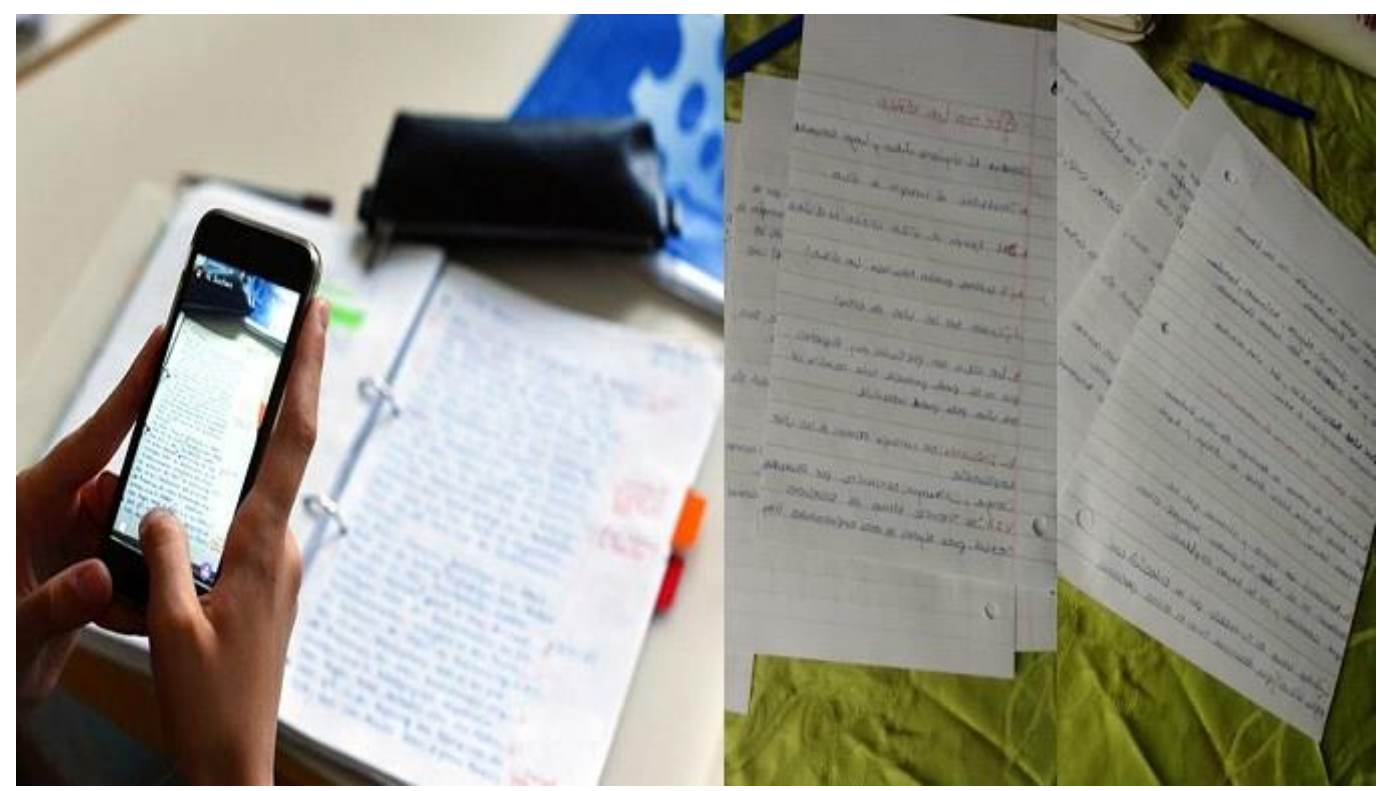

Figure 4. Screenshots of the task carried out by a student on the teacher's cell phone

\section{DISCUSION AND CONCLUSIONS}

This case study has allowed us to obtain holistic information, though necessarily fragmented and incomplete, about the forces that mediate the educational use of ICT in schools during the pandemic. In particular, we have made it possible to elucidate the impact of policies on the use of ICT and other political initiatives (Benavides \& Pedró, 2007) paying special attention to: organizational issues related to time and the reality of each student; the role of students and the place of ICT, the conditions of access to technology.

On the one hand, we can consider that this study is limited to a single interview with a single teacher, and a group from a particular school, and this limits the scope of the study. But we can see in general terms that during the quarantine, most of the students have used the cell phone that was available at home, mostly from the father or mother of the family, demonstrating that programs such as the "Programa conectar Igualdad" did not achieve the goal of digital inclusion at home because the integration was pretty superficial, in this sample validated by the opinion of the teacher. This reason arises because before the pandemic, teachers did not frequently use netbooks in class and students did not have access to the necessary knowledge to take advantage of the tool and teachers had many difficulties using netbooks.

On the other hand, WhatsApp, was not only an instant messaging channel, but currently teachers and students have given it an educational purpose (Lantarón, 2018), promoting collaborative work and the exchange of content in favor of its development, which has awakened the need for teachers to be part of the transformative drive for the benefit of education. Additionally, due to the lack of resources and when teachers saw that WhatsApp, it has always allowed them to maintain contact with students since it allows making or receiving calls or video calls for free and communicating with and between students, teachers in inaccessible areas with more connectivity difficulties (Gazzo, 2020). Another drawback that is inferred from the use of cell phones is that although, at the national level, training on the use of ICTs has been carried out for years, it must be said that they are not mandatory, nor immediately applicable. In addition, teaching in virtual environments has its own characteristics and leads to different teaching practices, which not everyone is in a position to sustain. It can be seen that in the face of this proposal, the school has not been able to fully advance in facing the containment of students due to the serious situation faced by students with parents who closed their sources of income.

From what was contributed by the teacher through the interview and the strategies used by the educators of this institution the interaction with students was made possible by the sending 
of activities for each curricular space by WhatsApp. He use of notebooks delivered in previous years has had little receptivity on the part of students, among other reasons due to the digital and technological inequalities that have been historically present and that became even more visible with the pandemic (Preti \& Fernández, 2020). It was also possible to avoid that both teachers and students were not prepared by multiple factors to enter education mediated by virtual platforms and applications. This evidenced that computers are needed to study, technological floors, training and connectivity for students from the suburbs. In addition to these problems, we can see that students in secondary school impacted them due to the economic crisis and many dropped out because they needed to have an income (Centro de Estudios de la Educación Argentina, 2017).

After the pandemic and the suspension of face-to-face classes, the parameters of education have been abruptly modified. The face-to-face link between the student and the teacher has not been present, nor between the students; and with which the dictation of the subjects was altered (Puiggrós, 2020). The realization of this proposed case study is situated in a constructionist conception of the investigation from the moment that it is proposed to reveal the dynamic contours of social reality and the processes by which configures and makes sense of it. It is an investigation that starts from the principle that the country we live in and the place we occupy are not simple and evidently there for the participants, but they configure the world and its constituent elements every day of their life. Reflect on social reality construction implies paying empirical attention to ordinary processes taken for granted and naturalized, as well as problematizing the most common understandings, the facts of experience that are usually treated as something to be directly discovered, noted, and analyzed.

Furthermore, in an investigation carried out by Zanona (2020), we see a proposal for the use of the cell phone as a digital pedagogical resource in a Buenos Aires high school and an intervention proposal for its use during the 2020 school year, within the framework of preventive social isolation and mandatory for COVID-19. Her conclusion provides that the cell phone, as a device, constitutes an advantage new resource, such as WhatsApp to motivate their students to keep learning; turn each difficulty into a new challenge to find new solutions, to discover a new project that will help them to continue developing professionally. We also find in the research by Coolican et al. (2020) that analyses the impact of the new coronavirus pandemic (COVID-19) in four educational and technical schools of the San Nicolás district in the province of Buenos Aires, Argentina, analyzing how teacher training can reshape practice and learning moving from the old to the new normal. In opposition, another study, like the one carried out by Mawarni et al. (2020), showed a negative response to the use of WhatsApp. It can be seen from the results of the study that students prefer to have face-to-face learning than online learning, and the existence of obstacles that students experience during the learning process through WhatsApp.

Our study describes and seeks as its main contribution how educational policies are often not adapted to the needs of students and teachers and do not have a long-term perspective, analyzed from a small but significant sample of the Buenos Aires suburbs. As it can be seen, many programs such as the one we analyze imply the delivery of the netbooks to the students, accompanied by some training, as an option in the formation of the pedagogical teaching process and not as a way of teaching but as a complement to teaching. The pandemic has shaken the entire educational system, putting aside discussions in the educational authorities as if the cell phone had to enter the classrooms, since it now became an indispensable tool making the educational reality visible (Andreatta \& Melia, 2020). Both from the perspective of the teacher and the students, we can see inequalities, which already existed prior to the pandemic, but which became more evident in a pandemic context. The State must be able to guarantee access to education, but also the different sectors involved must contribute to a complex panorama, such as the pandemic. In this work we saw that there was a strong pedagogical work by the teachers, with a didactic configuration adaptable to the context and the devices that are counted. With which a great effort of teachers and directors is used to maintain, in some way, contact with students and prevent abandonment. This type of situation leads one to think that many students will have to recover the learning that has been divided in the context of the pandemic because the continuity has been fragmented from many students and give more time for everything that has not been possible to build in this time of discontinuity (Álvarez et al., 2020). 
Finally, in relation to future work, we will try to analyze and study other software such as Instagram and the impact of its use in didactic planning, as a device to promote student learning in the context of a pandemic and also try to analyze the correlation between those who have more access to technology and the possibilities and access to learning, and the impact on digital citizenship. We will also seek to analyze group and cross-sectional work between students and teachers with age groups from other populations such as the university. Finally, we can think that virtual education expanded horizons through different tools such as WhatsApp, to try to give continuity to the face-to-face model from homes.

\section{LINKS}

In the following link you can find the survey published by WhatsApp in Word format: https://bit.ly/3v26Jwx

\section{BIBLIOGRAPHIC REFERENCES}

Alderete, M. \& Formichella, M. (2016). Efecto de las TIC en el rendimiento educativo: EI Programa Conectar Igualdad en la Argentina. Revista CEPAL, 119, 89-107. https://bit.ly/3dPWISZ

Alderete, M. \& Formichella, M. (2017). El acceso a las TIC en el hogar y en la escuela: su impacto sobre los logros educativos. Revista de Economía del Rosario,19(2). http://dx.doi.org/10.12804/revistas.urosario.edu.co/economia/a.5626

Álvarez, M., Gardyn, N., lardelevsky, A. \& Rebello, G. (2020). Segregación educativa en tiempos de pandemia: Balance de las acciones iniciales durante el aislamiento social por el Covid-19 en Argentina. Revista Internacional de Educación para la Justicia Social, 9(3), 2543. https://doi.org/10.15366/riejs2020.9.3

Anderete-Schwal, M. (2020). Las desigualdades educativas durante la pandemia en la educación primaria de Argentina. Revista Andina De Educación, 4(1), 5-10. https://doi.org/10.32719/26312816.2021.4.1.1

Andreatta, A. \& Melia, M. (2020, 23 de diciembre). EDUCACIÓN Y PANDEMIA. Aportes para pensar una nueva realidad. https://bit.ly/3dNwdbq

Artopoulos, A. (2020). COVID-19: ¿Qué hicieron los países para continuar con la educación a distancia? Revista Latinoamericana de Educación Comparada, 17, 1-11.

https://bit.ly/3sxA2Ws

Benavides, F. \& Pedró, F. (2007). Políticas educativas sobre nuevas tecnologías en los países iberoamericanos. Revista Iberoamericana De Educación, 45,19-69. https://doi.org/10.35362/rie450726

Cardini, A. \& Sanchez, B. (21 de abril de 2020) ¿Qué sabemos de los docentes en Argentina? Datos nuevos, desafíos que persisten. https://bit.ly/3eDemme

Centro de Estudios de la Educación Argentina (Octubre de 2017). La desigualdad en la escuela primaria argentina. https://bit.ly/2NJJxmv

Coolican, M., Borras, J. \& Strong, M. (2020). Argentina and the COVID-19: Lessons learned from education and technical colleges in Buenos Aires Province. Journal of Education for Teaching, 46(4), 484-496. http://doi.org/10.1080/02607476.2020.1802204

Expósito, E. \& Marsollier, R. (2020). Virtualidad y educación en tiempos de COVID-19. Un estudio empírico en Argentina. Educación y Humanismo, 22(39), 1-22. https://doi.org/10.17081/eduhum.22.39.4214

Fernández-Carballo, R. (2001). La entrevista en la Investigación cualitativa. Revista Pensamiento Actual, 2(3), 14-21. https://doi.org/10.15517/pa.v2i3 
Fondo de las Naciones Unidas para la Infancia (14 de mayo de 2020). COVID-19: UNICEF aporta evidencias sobre el impacto de la pandemia en la educación de los chicos y chicas de todo el país. https://uni.cf/3uFJKYr

Gazzo, M. (2020). La educación en tiempos del COVID-19: Nuevas prácticas docentes, ¿nuevos estudiantes?, Red Sociales. Revista del Departamento de Ciencias Sociales, 7(2), 58-63. https://bit.ly/2ZVVic4

Giuliano, M. \& Pacheco, G. (2015). Programa Conectar Igualdad: su impacto en el sistema educativo argentino como recurso de inclusión social. Signos Universitarios: Revista de la Universidad del Salvador, 1, 255-264. https://bit.ly/3dYzmoG

Grasso, M., Pagola, L. \& Zanoti, A. (2017). Políticas de inclusión digital en Argentina:usos y apropiaciones dentro y fuera de la escuela. Píxel-Bit. Revista de Medios y Educación, 50, 95-107. http://dx.doi.org/10.12795/pixelbit.2017.i50.06

Grimson, A. \& Tenti Fanfani, E. (2014). Mitomanías de la educación argentina. Crítica de las frases hechas, las medias verdades y las soluciones mágicas. Siglo Veintiuno. https://bit.ly/3rcoVC5

Johnson, M., Saletti-Cuesta, L. \& Tumas, N. (2020). Emociones, preocupaciones y reflexiones frente a la pandemia del COVID-19 en Argentina. Ciência \& Saúde Coletiva, 25, 2447-2456. https://doi.org/10.1590/1413-81232020256.1.10472020

Lago-Martínez, S. (2015). La inclusión digital y la educación en el Programa Conectar Igualdad. Educação, 38(3),340-348. https://bit.ly/3pYrAh9

Lantarón, B. (2018). WhatsApp: su uso educativo, ventajas y desventajas. Revista de Investigación en Educación, 16(2), 121-135. https://bit.ly/3kq04rM

Marchetti, B. \& Aguirre, J. (2020). Formación docente, inclusión digital y desigualdad educativa. Reflexiones narrativas sobre la discontinuidad de políticas y programas inclusivos en el nivel formador. Revista de Educación, 22, 89-110. https://bit.ly/3rbZ1hq

Mawarni, I.T., Ratnasari, N., Handayani, A.N., Muladi, M., Wibowo, E.P. \& Untari, R.S. (2020). Effectiveness of Whatsapp in Improving Student Learning Interests During The Covid-19 Pandemic. 2020 4th International Conference on Vocational Education and Training (ICOVET), 248-252. http://doi.org/10.1109/ICOVET50258.2020.9230031

Ministerio de Educación de la Nación (2020). Informe Preliminar Encuesta a Hogares. Continuidad pedagógica en el marco del aislamiento por COVID-19. Ministerio de Educación de la Nación de la Ciudad Autónoma de Buenos Aires. https://bit.ly/2SUpXWQ

Observatorio Argentinos por la Educación (Agosto de 2020). La educación argentina durante la pandemia de COVID-19. Un estudio sobre la situación de familias y alumnos durante el aislamiento. SEGUNDO INFORME Dispositivos y medios de comunicación para mantener el vínculo pedagógico en cuarentena. https://bit.ly/2R53iGk

Preti, M. \& Fernández, M. (2020). Educación y desigualdade socioeconómica. Políticas públicas en tempos de pandemia (República Argentina). CAMINHOS DA EDUCAÇÃO: diálogos, culturas e diversidades, 2(2), 22-42. https://doi.org/10.26694/caedu.v2i2.11242

Puiggrós, A. (2020). Balance del estado de la educación, en época de pandemia en América Latina: el caso de Argentina. En Dussel, I. Ferrante, P. y Pulfer, D. (Eds.), Pensar la educación en tiempos de pandemia. Entre la emergencia, el compromiso y la espera, (pp. 33-42). Universidad Pedagógica Argentina. https://bit.ly/3hCwv6Q

Sandoval, C. (2020). La educación en tiempo del Covid-19 herramientas TIC: El nuevo rol Docente en el fortalecimiento del proceso enseñanza aprendizaje de las prácticas educativa innovadoras. Revista Tecnológica - Educativa Docentes 2.0, 9(2),24-31. https://doi.org/10.37843/rted.v9i2.138

Sanguinetti, H. (2007). La educación Argentina en un laberinto. Fondo de Cultura Económica 
Serrano, R. (2009). Cuéntame tu experiencia en el curso on line. Empleo de la entrevista cualitativa como técnica para la investigación cualitativa. Quaderns digitals: Revista de Nuevas Tecnologías y Sociedad, 59,1-17. https://bit.ly/2NBonaP

Suasnabar, C. (2007). Educación, conocimiento y política: Argentina, 1983-2003. Manantial

Sunkel (2006). Las tecnologías de la información y la comunicación (TIC) en la educación en América Latina. Una exploración de indicadores. Serie Políticas Sociales 126. Comisión Económica para América Latina y el Caribe. División de Desarrollo Social. https://bit.ly/3uBs6Fi

Sunkel (2009). Las TIC en la educación de América Latina visión panorámica. Serie de la colección TIC. Organización de Estados Iberoamericanos para la Educación, la Ciencia y la Cultura (OEI) y Fundación Santillana. https://bit.ly/2PdxmyF

Tedesco, J. (2015). La educación argentina hoy. La urgencia del largo plazo. Siglo Veintiuno. https://bit.ly/3ou6KXI

Tiramonti, G. (25 de octubre de 2017). La educación atrasa 50 años. La Nación. https://bit.ly/2O3NdPO

Vasilachis, I. (2006). La investigación cualitativa. Gedisa.

Zanona, A. (2020). El uso del celular como recurso pedagógico digital en una escuela secundaria bonaerense. Propuesta de intervención para su uso durante el ciclo lectivo 2020, en el marco del aislamiento social preventivo y obligatorio por COVID19. [Trabajo de Fin de Grado, Universidad Abierta Interamericana]. https://bit.ly/3gtYHZ5

\section{INFORMACIÓN SOBRE LOS AUTORES}

\section{Antonieta Kuz}

Universidad Metropolitana para la educación y el trabajo (Argentina)

Dra. en Ciencias de la Computación especializada en TIC y educación, es investigadora independiente. Actualmente se desempeña como docente en la Universidad Metropolitana para la educación y el Trabajo y en la Escuela Superior de Guerra Conjunta y realiza actividades de gestión de EVAs y capacitaciones. Ha escrito numerosas investigaciones en torno a la temática de la tecnología y la educación y ha desarrollado software de autor destinados a mejorar los procesos de enseñanza aprendizaje. También es autora de un libro "Aprender a Enseñar: un puente de experiencias y posibilidades tecnológicas" (editorial Dunken), 2019. Cuenta con un instagram donde frecuentemente publica las tendencias en educación: @aprenderaeducarcontic

Los textos publicados en esta revista están sujetos a una licencia de Reconocimiento 4.0 España de Creative Commons. Puede copiarlos, distribuirlos, comunicarlos públicamente y hacer obras derivadas siempre que reconozca los créditos de las obras (autoría, nombre de la revista, institución editora) de la manera especificada por los autores o por la revista. La licencia completa se puede consultar en:Licencia Creative Commons Atribución-NoComercial-Compartir por igual 4.0 Internacional. 